\title{
Daunting costs for clean-up at Hanford
}

\section{- Large amounts of waste involved - Millions of dollars needed}

\section{Boston}

OfFicials from the United States Energy Department and from Washington state signed an agreement last week that sets in motion a massive 30 -year project to clean up Washington's Hanford Military Reservation, the nation's most troubled nuclear fuel production facility. The agreement outlines the legal and technical details of the clean-up, establishes a timetable for the project, and commits the Energy Department publicly to the effort. It does not, however, include an appropriation of money to do the job, which must come from Congress.

The Hanford agreement was welcomed in all quarters. In a written statement, Energy Department Secretary James D. Watkins declared Hanford's clean-up to be "of utmost importance" and added that the agreement "properly emphasizes" the attention that the job requires from the federal agency.

Washington Governor Booth Gardner hailed the fact that the clean-up would begin "at long last". And representatives from environmental groups and from the regional office of the Environmental Protection Agency say the agreement can be used as a model to guide the clean-up

efforts at other Energy Department facilities around the nation.

But all parties are concerned about the feasibility of the clean-up agreement because of the expense involved. The scale of the effort will be unprecedented. According to the Energy Department's own estimates, the project could cost as much as $\$ 57,000$ million, requiring a sustained federal outlay of close to $\$ 2,000$ million a year to get the job done on time.

Expenditure on that scale at a single site is almost inconceivable in the current fiscal environment according to several congressional insiders, especially because Hanford is only one (albeit the largest) of the clean-up projects that will be required at the Energy Department's 16 weapons production facilities. The Energy Department's entire budget for fiscal year 1989 is roughly $\$ 14,000$ million.

The enormous cost of the project stems in large part from the amount of waste involved. At the 560-square mile Hanford Reservation is an estimated 30 million cubic feet of nuclear waste and perhaps as much as one hundred times that amount of contaminated soil - the accumulation of more than four decades of radioactive by-products of plutonium production at

ATMOSPHERIC SCIENCES

\section{NERC plans to double its expenditure}

\section{London}

THE UK Natural Environment Research Council (NERC) plans to double its expenditure on atmospheric sciences in universities next year, giving priority to global atmospheric modelling, tropospheric chemistry and meso-scale meteorology. And to highlight the new emphasis, the council is creating a new 5-year post for a director of atmospheric sciences; setting up a committee to distribute research funds in this area; and renaming the Marine Sciences Directorate as the Marine and Atmospheric Sciences Directorate.

John Bowman, secretary of NERC, says that until now the atmospheric sciences have been the 'Cinderella' of the NERC: research funds have been scarce and the research community is small. Last year, NERC spent only $£ 1.5$ million ( 1 per cent of the research budget) on the atmospheric sciences (excluding about $£ 5$ million on the British Antarctic Survey).

The council is requesting $£ 1.5$ million more from the national science budget next year. The sum is modest admits Bowman, but any more would be disproportionate to the size of the research community. The council plans to increase resources gradually. In the first policy document for the atmospheric sciences, published last week, priority areas of research were outlined.

More than half the money requested for next year will be spent on UGAMP (the Universities Global Atmospheric Modelling Project) which develops climate models and analyses their products. It currently involves only 20 researchers and has a budget of only $£ 100,000$.

If NERC's request is approved, UGAMP's budget will increase to $\$ 800,000$, an indication that the council is finally taking the atmospheric sciences seriously, says Professor Brian Hoskins of the University of Reading, a member of the UGAMP steering committee. If there were no increase in resources, the prospects for the research community would be "dire". The atmospheric sciences desperately need to attract good chemists, physicists and mathematicians, he says.

Christine McGourty the facility. Workers at the Hanford site conducted the world's earliest large-scale effort to produce weapons-grade plutonium, and manufactured the plutonium used in the bomb dropped on Nagasaki in the Second World War. Following the war, Hanford served as a key location for military plutonium production and processing, housing a total of nine production reactors, all of which are now shut down.

The astronomical cost of the project also reflects the high level of radioactivity present in some of the waste and the difficulty of handling it in its current state. More than 500,000 gallons of high-level liquid wastes are known to have leaked from at least 58 underground tanks at the site, and much more leakage is suspected at another 100 tanks. The leached waste liquid and the remaining sediment in the tanks themselves - both extremely radioactive - present a daunting technical challenge for the environmental restoration project. The Energy Department has yet to offer specific technical solutions.

The high cost of the project also reflects the variety of clean-up activities required. In addition to the high-level liquid wastes found on the site, Hanford's nuclear reactors themselves contain radioactive residues and must be dismantled (see Nature 339, 90; 11 May 1989). Last month, the Energy Department issued a 300-page environmental impact statement showing the gigantic scale of just this part of the clean-up, with costs estimated at nearly $\$ 200$ million.

Environmentalists involved in the issue reacted favourably to the Hanford agreement but representatives from several groups expressed dismay over "lax provisions" in addressing current practices at the site. Lindy Cater, executive director of the Hanford Education Action League (HEAL), which is credited with publicly disclosing many of the environmental problems at the site, complains that while the agreement covers existing waste, it "fails to address ongoing waste production at Hanford's PUREX plutonium processing facility".

HEAL had urged previously that the clean-up agreement be tied to a stop to plutonium processing at PUREX, which according to one estimate produces 23 million gallons of water containing low levels of radioactive and chemical wastes in every day of operation.

In response to these complaints, the state of Washington announced that, in addition to the agreement, it will take part in a 14-month investigation of the current waste stream from Hanford's plutoniumprocessing facility. Officials said that this investigation will seek to determine the threat posed by the waste stream, and whether the state will call for a halt to processing before the 1995 deadline in the agreement.

Seth Shulman 